\title{
PCR-based diagnosis of Helicobacter pylori infection in Polish children and adults
}

\author{
A. GZYL, D. DZIERŻANOWSKA, E. ROŻYNEK,D. CELIŃSKA-CEDRO*, W. DURA ${ }^{\dagger}$ and D. E. BERG ${ }^{\ddagger}$ \\ Departments of Clinical Microbiology, *Gastroenterology and †Histopathology, The Children's Memorial Health \\ Institute, Dzieci Polskich Avenue 20, 04-736 Warsaw, Poland and $¥$ Department of Molecular Microbiology, \\ Washington University, St. Louis, MO, USA
}

\begin{abstract}
Infection and associated disease caused by Helicobacter pylori are common in Poland, as in much of Eastern Europe, although the genotypes of strains have not been much studied, especially in terms of traits that might be important in disease. This study developed a sensitive and efficient polymerase chain reaction (PCR) test for the presence of $H$. pylori in gastric biopsy samples with ure $A$ gene-specific primers and primers for the virulence-associated cag pathogenicity island (PAI). These tests were used with biopsy samples from 246 symptomatic children (age range 1-17 years) and 82 adults (age range 18-53 years) in Warsaw. An assessment was also made of the success of metronidazole-based therapy intended to eradicate infection. $H$. pylori was detected by ure $A$-specific PCR in $83(76.9 \%)$ children and in $41 .(87.2 \%)$ adults with histologically proven gastritis, and in $28.4 \%$ and $29.2 \%$, respectively, of the 38 children and 7 adults with little or no evidence of gastritis. In general, $\boldsymbol{H}$. pylori was detected more often by PCR than by culture $\mathbf{7 0 . 3 \%}$ compared with $52.8 \%$ in children and $62.8 \%$ compared with $38.6 \%$ in adults), although in several cases a negative PCR was associated with a positive culture result. The rate of $H$. pylori infection increased with age from $5.4 \%$ in children up to 5 years old to $29.2 \%$ to age 10 and $65.4 \%$ to age 18 . The tests detected the cagPAI in $97(75 \%)$ and $44(85 \%)$ of the $H$. pylori-infected children and adults, respectively. Some $H$. pylori-infected patients with a ureA+ PCR result contained the 'empty site' of the cagPAI and only four patients were infected with mixed cag + cagstrains. PCR with cagPAI and 'empty site' of the cagPAI represents a novel tool for fast screening of mixed cag + cag - infection. These results confirm and further illustrate that direct PCR of biopsy specimens can be useful for detection of infection and genotyping of resident strains, and that $H$. pylori infection is very common among children as well as adults in Poland. They also show that Polish strains vary with regard to the presence or absence of the cagPAI, and suggest that the proportion of strains that are cag + is higher in Poland than in Western European countries, which may reflect the relatively higher risk of infection in this society.
\end{abstract}

\section{Introduction}

Helicobacter pylori is a micro-aerophilic gram-negative bacterium that establishes chronic infections in man throughout the world [1,2]. It is implicated as a primary cause of gastritis and duodenal and gastric ulcers, and as a critical early risk factor for gastric cancer, with most infections being asymptomatic [1-6]. The incidence of infection is much higher in developing countries and probably higher in Eastern

Received 5 Jan. 1998; revised version accepted 14 July 1998. Corresponding author: Dr A. Gzyl, Department of Sera and Vaccines Control, National Institute of Hygiene, Chouinska FFr. 24, 00-791, Warsaw, Poland.
Europe than in Western Europe or North America $[1,2,5,7-12]$. This is considered to reflect transmission primarily by faecal-oral and oral-oral routes or through recently contamined food and water, or both [9].

H. pylori is an extremely diverse species, and several genetic markers that are present in only a subset of Western European or American strains and that are virulence-associated epidemiologically have been identified $[1,10,13]$. Prominent among them is the cag pathogenicity island (cagPAI), a 37-kb DNA segment many of whose encoded functions seem to help elicit synthesis of the pro-inflammatory cytokine interleukin8 (IL-8) and thus, probably, do much to stimulate 
inflammatory responses that contribute significantly to the risk or severity of disease $[1,10,14,15]$.

Tests in many countries have shown that eradication of $H$. pylori from patients with peptic ulcer generally results in permanent cure of disease.

The worldwide distribution and high prevalence of $H$. pylori and its importance in disease have stimulated interest in efficient detection of infection, especially by strains of potentially more virulent genotypes. Traditionally, diagnosis was dependent on culture from gastric biopsy samples or visualisation during histological examination. Although culture is important, the bacterium is slow-growing and fastidious, and it is possible that some $H$. pylori strains will not form colonies on currently available media [16]. Histological detection also has drawbacks, especially in sensitivity of detection of current infection [17]. Accordingly, several laboratories have developed polymerase chain reaction (PCR)-based detection in the expectation that it would be far faster and perhaps more sensitive, efficient and reliable then other detection methods.

This report describes the implementation of PCRbased detection of $H$. pylori in gastric biopsy samples and thus of active infection in a large cohort of children and adults in Warsaw, Poland, and the preliminary use of PCR to characterise polymorphic virulence determinants. PCR with ure $A$-specific primers was considerably more sensitive, faster and less laborious than culture for detection of $H$. pylori in biopsy specimens. PCR detection of the cagPAI and 'empty site' of cagPAI served as a sensitive tool for estimating the prevalence of this virulence-associated factor in strains isolated in the study poplation and determination of the number of mixed infections with cag + cag - strains.

\section{Material and methods}

\section{Clinical specimens}

All patients enrolled in this study attended the Outpatient Gastroenterology Department at The Children's Memorial Health Institute (CMHI) with dyspepsia or upper gastrointestinal tract disorders during the period 1993-1996, and gave informed consent for use of their biopsy material for clinical research. The research protocol was approved by the Human Studies Committee of CMHI in accordance with Polish national guidelines for protection of patients' rights. At least three biopsy samples were taken from the gastric antrum and additional biopsy samples were taken from the duodenum in some cases. They were then processed routinely for histopathology, bacteriology and PCR tests. Specimens for culture were placed immediately in phosphate-buffered saline $(0.9 \%)$ on ice, and transported to the laboratory. A total of 246 children (122 girls, 124 boys; average age, 13.5 years, range 1-17 years) and 74 adults (average age 36.8 years) was studied. Eradication therapy generally consisted of metronidazole, amoxycillin (20 mg/ $\mathrm{kg} /$ day for 10 days) and bismuth salts (Ventrisol: $7-8 \mathrm{mg} / \mathrm{kg} /$ day for 6 weeks) and its efficacy was checked by culture and PCR in 44 children.

\section{Bacterial strains}

Gastric biopsy samples taken during endoscopy were homogenised and cultured on Wilkins Chalgren medium with horse blood $7 \%$, vancomycin $10 \mathrm{mg} / \mathrm{L}$, trimethoprim $5 \mathrm{mg} / \mathrm{L}$, cefsulodin $5 \mathrm{mg} / \mathrm{L}$ and cycloheximide $100 \mathrm{mg} / \mathrm{L}$. Plates were incubated in a microaerophilic atmosphere with $\mathrm{CO}_{2} 5-8 \%$ at $37^{\circ} \mathrm{C}$ for $5-7$ days. Species identification was based on colony and cell morphology and on biochemical tests for oxidase, catalase and urease by use of API CAMP and Rapidec pylori (bioMérieux) tests [16]. All cultured strains were stored in brain heart infusion broth with glycerol at $-70^{\circ} \mathrm{C}$. H. pylori ATCC43504 and H. pylori 26695 cagA + were used as reference strains. The latter was used for full genome sequencing [18] and both contained the cagPAI.

\section{Histopathology}

Several sections cut from each embedded biopsy sample were stained with haematoxylin and eosin and examined to assess the histopathological status of the mucosa. Histological examination was performed in the Department of Pathomorphology, CMHI. Every biopsy specimen was assessed by the pathologist in terms of chronic, acute or a special form of gastritis. In chronic gastritis the predominant cell infiltrate consisted of lymphocytes and plasma cells and was scored as mild, moderate or severe. The presence of neutrophil granulocytes in the lamina propria or intra-epithelial sites, or both, determined its activity, and loss of gastric gland indicated atrophy. In acute gastritis, the predominant cell infiltrate consisted of neutrophils either in the lamina propria or in intra-epithelial sites or both [17].

\section{Preparation of DNA from biopsy specimens}

Biopsy specimens suspended in $0.5 \mathrm{ml}$ of $\mathrm{NaCl} 0.9 \%$ were centrifuged at $2300 \mathrm{~g}$ for $5 \mathrm{~min}$ and the pellet was resuspended in $300 \mu \mathrm{l}$ of extraction buffer $(20 \mathrm{mM}$ Tris-HCl, $\mathrm{pH} 8.0$; Tween $20 \quad 0.5 \%$ ) and $3 \mu \mathrm{l}$ of proteinase K $(200 \mu \mathrm{g} / \mathrm{ml})$ were added. Samples were incubated for $1-2 \mathrm{~h}$ at $55^{\circ} \mathrm{C}$ to ensure complete lysis. Proteinase $\mathrm{K}$ was inactivated by heating at $98^{\circ} \mathrm{C}$ for 10 min [19]. DNA was extracted twice with a mixture of phenol:chloroform:isoamyl alcohol $(25: 24: 1)$ and twice with chloroform:isoamyl alcohol (24:1). DNA was precipitated with one-tenth volume of $3 \mathrm{M}$ sodium acetate, pH 5.5, and absolute ethanol [19]. Samples 
were incubated for $1 \mathrm{~h}$ at $-70^{\circ} \mathrm{C}$ and then were centrifuged at $13100 \mathrm{~g}$ for $30 \mathrm{~min}$ at $4^{\circ} \mathrm{C}$. The DNA pellet was washed in ethanol $70 \%$, dried and resuspended in $40 \mu \mathrm{l}$ of TE buffer $(10 \mathrm{mM}$ Tris, $1 \mathrm{mM}$ EDTA). The quality and quantity of DNA were determined spectrophotometrically at $260 \mathrm{~nm}$ and $280 \mathrm{~nm}$ and by electrophoresis of samples in an agarose $1 \%$ gel with diluted preparations of $\lambda$ phage DNA of known concentrations.

\section{Amplification of $H$. pylori gene encoding urease $A$ fragment}

PCR to detect $H$. pylori was performed with primers that had been developed and validated by Clayton et al. [20]. PCR with HPU 1-5' GCCAATGGTAAATTAGTT $3^{\prime}$ and HPU 2-5' CTCCTTAATTGTTTTTAC 3' yields a 411-bp fragment on amplification [20]. PCR was performed in a volume of $50 \mu \mathrm{l}$ in a Gen Amp 9600 thermocycler (Perkin Elmer). The mixture contained: incubation buffer $10 \times(10 \mathrm{mM}$ Tris- $\mathrm{HCl}, \mathrm{pH} 8.3$; $50 \mathrm{mM} \mathrm{KCl} ; 2.5 \mathrm{mM} \mathrm{MgCl}_{2}$; gelatin $0.001 \%$; four deoxyribonucleotides, $100 \mu \mathrm{M}$ each; primers, $50 \mathrm{pmol}$ each; Taq polymerase (Boehringer) $2 \mathrm{U}$ and $0.5-1 \mu \mathrm{g}$ of target DNA. The following cycle conditions were used: denaturation $94^{\circ} \mathrm{C}, 4 \mathrm{~min}$, followed by 35 cycles of denaturation $\left(94^{\circ} \mathrm{C}, 1 \mathrm{~min}\right)$, annealing $\left(45^{\circ} \mathrm{C}, 1 \mathrm{~min}\right)$, extension $\left(72^{\circ} \mathrm{C}, 1 \mathrm{~min}\right)$ and a final extension step $\left(72^{\circ} \mathrm{C}, 5 \mathrm{~min}\right)$. PCR on genomic DNA from $H$. pylori strain ATCC43504 and glass-distilled pure water were used as positive and negative controls, respectively.

\section{Sensitivity of the PCR assay}

To assess the sensitivity of the ure $A$ PCR, a suspension of ATCC 43504 containing c. $5 \times 10^{5} \mathrm{cfu} / \mathrm{ml}$ was diluted and the number of bacteria was calculated from the McFarland standard, and samples of sequential 10fold dilutions were also spread quantitatively on Wilkin's-Chalgren medium and cultured for 5-7 days. DNA was extracted from known numbers of ATCC 43504 cells and used in the PCR as described above to determine the smallest number of cells $(\mathrm{cfu} / \mathrm{ml})$ that could be detected by PCR (primers HPU1, HPU2).

\section{Control of PCR-negative results}

Host globin gene amplification was performed on DNA extracts from biopsy samples in each case in which ure A-PCR gave a negative result to test for possible inhibitors of PCR. This entailed use of the $\beta$-globinspecific primers: BGLO 1-5' ACACAACTGTGTTCACTAGC- $3^{\prime}$ and BGLO 2-5' CAACTTCATCCACGTTCACC $-3^{\prime}$ as a control of possible inhibition of reaction in lysates and DNA samples obtained from biopsy specimens. Amplification of the 110-bp fragment of the gene encoding $\beta$-globin signified the lack of inhibitors in the sample [21]. The reaction was performed in a volume of $50 \mu \mathrm{l}$ in a Gen Amp 9600 thermocycler. The mixture contained: incubation buffer $10 \times(10 \mathrm{mM}$ Tris$\mathrm{HCl}$, pH $8.3 ; 50 \mathrm{mM} \mathrm{KCl} ; 2.5 \mathrm{mM} \mathrm{MgCl}_{2}$; gelatin $0.001 \%$ ); four deoxyribonucleotides, $100 \mu \mathrm{M}$ each; primers, $50 \mathrm{pM}$ each; Taq polymerase (Boehringer) $2 \mathrm{U}$; and $0.5-1 \mu \mathrm{g}$ of target DNA or $5 \mu \mathrm{l}$ of lysate. The conditions for the PCR reaction were: denaturation $\left(95^{\circ} \mathrm{C}, 5 \mathrm{~min}\right)$ followed by 35 cycles of denaturation $\left(94^{\circ} \mathrm{C}, 1 \mathrm{~min}\right)$, annealing $\left(45^{\circ} \mathrm{C}, 1 \mathrm{~min}\right)$; extension $\left(72^{\circ} \mathrm{C}, 1 \mathrm{~min}\right)$ and final extension $\left(72^{\circ} \mathrm{C}, 7 \mathrm{~min}\right)$.

\section{Detection of the cagPAI region and the 'empty site' of the cagPAI by PCR}

All DNA extracts from biopsy specimens that were PCR-positive for the urease subunit A gene of $H$. pylori were additionally tested for the presence of cagPAI. The chosen primers - Luni 1-5'-ACATTTTGGCTAAATAAACGCTG- $3^{\prime}$ and L cag1-5'TCTCCATGTTGCCATTATGCT-3' - are specific for the left end of virulence-associated 37-kb DNA fragment [15]. Amplification of cagPAI-positive $H$. pylori samples yields a 360-bp fragment. The PCR was performed in a volume of $50 \mu 1$ in a Gen Amp 9600 thermocycler. The mixture contained: incubation buffer $10 \times(10 \mathrm{mM}$ Tris-HCl, pH $8.3 ; 50 \mathrm{mM} \mathrm{KCl} ; 2.5 \mathrm{mM}$ $\mathrm{MgCl}_{2}$; gelatin $0.001 \%$ ); four deoxyribonucleotides, $100 \mu \mathrm{M}$ each; primers, $50 \mathrm{pmol}$ each; Taq polymerase (Boehringer) $2 \mathrm{U}$; and $0.5-1 \mu \mathrm{g}$ of target DNA.

Primers Luni 1-5'ACATTTTGGCTAAATAAACGCTG-3' and Rnew1-5'TCATGCGAGCGGCGATGTG$3^{\prime}$ determined the amplification of the 360-bp fragment of DNA representing the 'empty site' of the whole pathogenicity island in which other chromosomal genes (HP05419 and HP0549 in the TIGR database [18]) that had been separated by the $37-\mathrm{kb}$ segment were now adjacent to one another [15]. The same quantities of mixture reagents were used for PCR amplification. The primer sequences were kindly provided by Prof. D. E. Berg (Washington University, St Louis, USA). The conditions for the PCR were: denaturation $\left(94^{\circ} \mathrm{C}, 4 \mathrm{~min}\right)$, followed by 35 cycles of denaturation $\left(94^{\circ} \mathrm{C}, 1 \mathrm{~min}\right)$, annealing $\left(57^{\circ} \mathrm{C}, 1 \mathrm{~min}\right)$ and extension $\left(72^{\circ} \mathrm{C}, 1 \mathrm{~min}\right)$ and final extension $\left(72^{\circ} \mathrm{C}\right.$, $5 \mathrm{~min}$ ). The positive control was amplification of DNA from $H$. pylori 26695 cagA + strain (provided by Prof. D. E. Berg). Distilled water provided a negative control.

\section{Detection of PCR products}

Amplification products were detected by electrophoresis in agarose $2 \%$ gels, stained with ethidium bromide $0.5 \mu \mathrm{g} / \mathrm{ml}$ and visualised under UV illumination (Pharmacia). Electrophoresis was performed in TBE buffer ( $89 \mathrm{mM}$ Tris-borate acid, 0.5 M EDTA, pH 8.0) in SUBDNA apparatus (Kucharczyk, Poland). Gels were photographed with a Polaroid camera. 


\section{Prevention of contamination}

Published recommendations [22] for elimination of PCR false results were followed strictly. Different work stations for DNA isolation, amplification and PCR product detection were separated physically. Different rooms were individually equipped. Decontamination was based on application of UV light between sessions and overnight.

\section{Primers}

All primers were synthesised by Universal DNA, Tigard, OR, USA.

\section{Results}

\section{Endoscopic and histopathological analysis}

The histopathology of antral biopsy samples taken during upper gastrointestinal endoscopy of 246 children (average age 13.5 years) and 74 adults (average age 36.8 years), each of whom had been recommended for endoscopy because of dyspepsia, was investigated. Among the 246 children, 107 (43.5\%) had evidence of gastritis, two had duodenitis with gastritis, one had duodenitis without evident gastritis and one had a duodenal ulcer with gastritis. Of the 74 adults tested, $47(63.5 \%)$ had gastritis, one had duodenitis and two had gastritis with duodenitis. No significant pathology was detected in the biopsy samples from any of the other 134 children and 24 adults scored, although just one biopsy sample was analysed from each patient.

\section{Detection of $H$. pylori infection}

The presence or absence of $H$. pylori infection was assessed by two complementary detection methods, each on a different gastric biopsy specimen: PCR with ure $A$ gene-specific primers and culture on Wilkins Chalgren medium (Table 1). Reconstruction tests with the type strain ATCC 43504 indicated that PCR could detect as few as $50 \mathrm{H}$. pylori cells per reaction (Fig. 1).
H. pylori was detected by ureA-specific PCR in 83 (76.9\%) of the 108 children and in $41(87.2 \%)$ of the 47 adults with histological gastritis and in 38 (28.4\%) of 134 children and $7(29.16 \%)$ of 24 adults in whom no gastric pathology was detected. $H$. pylori was detected by culture in 89 of the 124 children and 46 of the 51 adults found to be positive by PCR, and also in seven patients in whom $H$. pylori was not detected by PCR. In these negative samples, additional PCR with BGLO1 and BGLO2 primers was performed and the absence of 110-bp amplified fragments of the $\beta$ globin gene revealed the presence of inhibitors.

The frequency of $H$. pylori infection in children estimated by taking together positive culture and PCR results from $36.8 \%$ to $52.8 \%$ for children and from $63.5 \%$ to $70.3 \%$ for adults. Overall, sensitivities of PCR and culture were $98.3 \%$ and $81.1 \%$, respectively.

Amongst the 130 children with $H$. pylori infection $5.4 \%$ were $<5$ years old, $29.2 \%$ were $<10$ years old and $65.4 \%$ were $\leqslant 18$ years old.

\section{Efficacy of eradication}

Forty-four of the paediatric patients were treated with metronidazole, amoxycillin $(20 \mathrm{mg} / \mathrm{kg} /$ day for 10 days) and bismuth salts (Ventrisol $7-8 \mathrm{mg} / \mathrm{kg} /$ day for 6 weeks) to eradicate the $H$. pylori infections, and were then followed by periodic endoscopy. In 19 of these 44 patients, $H$. pylori was judged to have been eradicated by treatment, based on negative scores by follow-up endoscopy after 3-4 months for PCR, culture and histological examination. Eradication was associated with decreased inflammation and a more normallooking gastric mucosa by 3 months.

In 20 of the children, therapy was deemed to have failed on the basis of positive culture and PCR and no improvement in the condition of the gastric mucosa. In five children who still remained PCR positive, a lower intensity of inflammation was observed.

Table 1. Detection of $H$. pylori by culture and PCR in 246 children and 74 adults with different disease states

\begin{tabular}{lcccc}
\hline & \multicolumn{4}{c}{ Number (\%) of patients who were } \\
\cline { 2 - 5 } Disease state (n) & Cult+, PCR+ & Cult+, PCR- & Cult-, PCR+ & Cult-, PCR- \\
\hline Children & & & & \\
G (108) & $74(30.1)$ & $3(1.2)$ & $9(3.7)$ & $22(8.9)$ \\
G+DUO (2) & $1(0.4)$ & 0 & 0 & $1(0.4)$ \\
DUO (1) & $1(0.4)$ & 0 & 0 & 0 \\
UD+G (1) & $1(0.4)$ & 0 & 0 & 0 \\
N (134) & $12(4.9)$ & $3(1.2)$ & $26(10.6)$ & $93(37.8)$ \\
Total (246) & $89(36.2)$ & $6(2.4)$ & $35(14.3)$ & $116(47.1)$ \\
Adults & & & & \\
G (47) & $40(54.05)$ & $1(1.35)$ & $1(1.35)$ & $5(6.75)$ \\
G+DUO (2) & $1(1.35)$ & 0 & $1(1.35)$ & 0 \\
DUO (1) & $1(1.35)$ & 0 & 0 & 0 \\
N (24) & $4(5.4)$ & 0 & $3(4.05)$ & $17(23)$ \\
Total (74) & $46(62.2)$ & $1(1.35)$ & $5(6.8)$ & $22(27.7)$ \\
\hline
\end{tabular}

G, gastritis; G+DUO, gastritis + duodenitis; UD+G, duodenal ulcer + gastritis; DUO, duodenitis; $\mathrm{N}$, normal mucosa; Cult, culture. 
a
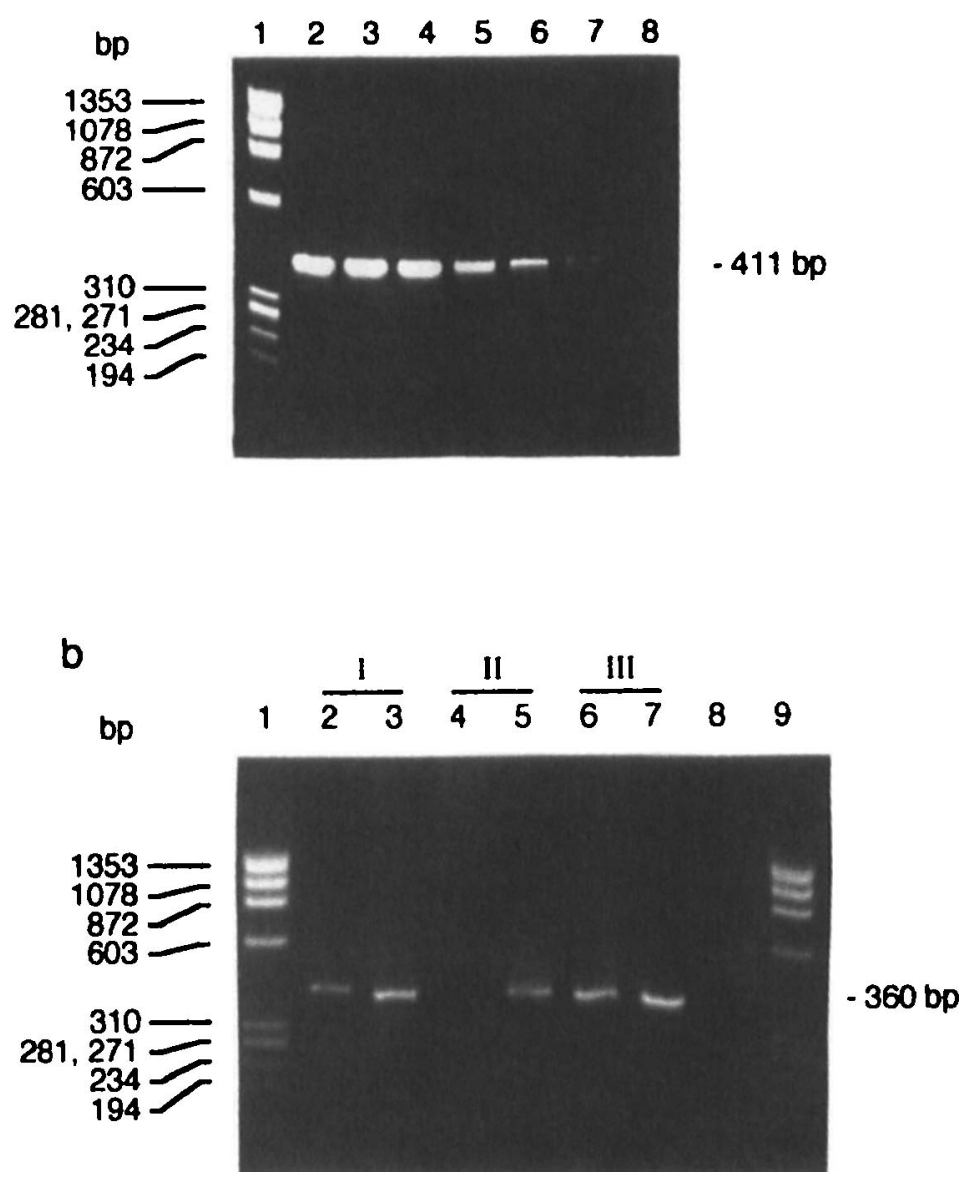

Fig. 1. PCR sensitivity and PCR detection of the cagPAI region and 'empty site' of the cagPAI. (a) Sensitivity of PCR assay (HPU1 and HPU2) for detection of H. pylori. (b) Detection of PCR products characterising presence of cagPAI or 'empty site' of cagPAI for three samples (I rows 2, 3; II rows 4, 5; III rows 6, 7). Lanes A1, B1, 9 X174RFI DNA Hae IIl marker; A2-8, results of amplification corresponding to dilutions of $H$. pylori ATCC 43504 control strain from $50 \times 10^{6}$ to $5 \mathrm{cfu} / \mathrm{ml} ; \mathbf{B 2}, 4,6$, amplification of the left end of the cagPAI (Luni 1 and Lcag1 primers); B3, 5, 7, amplification of the 'empty site' of the whole cagPAI (Luni 1 and Rnew 1); B8, negative PCR control.

\section{Direct detection of cagPAI in gastric biopsy specimens}

PCR was used to test for the presence of the cagPAI with primers specific for the left end of this virulenceassociated 37-kb DNA segment in DNA extracted from each biopsy specimen that had been scored as H. pylori-positive by ureA PCR (Table 2). As much as $74.6 \%$ of the 130 ureA PCR-positive biopsy specimens from children and $84.6 \%$ of 51 biopsy samples from adults were found to be cag + by this test. Complementary PCR was also performed with primers specific for the 'empty site' of the cagPAI region in which other chromosomal genes that had been separated by the $37-\mathrm{kb}$ cagPAI were now adjacent to one another [15]. Thirty-three and eight of the biopsy specimens from children and adults respectively, were scored as definitively cag- as they yielded a product with 'empty site'-specific primers. These included four patients whose samples were mixed (cag - and cag + in the cagPAI-specific PCR) by these tests. No ambiguous cases (neither cag- nor 'empty site') were observed.
Among those isolates that were PCR ureA-, but culture positive, the study could not evaluate the presence of the cagPAI because these isolates where negative for the $\beta$-globin gene, which is a marker for the presence of inhibitors. As many as $72(84 \%)$ of the $86 \mathrm{H}$. pylori-positive children with evident gastritis were found to be cag+, whereas $22(53.7 \%)$ of the 41 cases that were positive for $H$. pylori, but in whom no significant gastritis was observed, were found to carry the cagPAI. In ureA PCR-positive biopsy samples from 42 adults with evident gastritis, $37(88 \%)$ were found to be cag positive, whereas 4 $(57.1 \%)$ of 7 without gastritis were carrying the cagPAI.

\section{Discussion}

H. pylori infection in the stomach is an important aetiological factor in chronic active gastritis and in the development of peptic ulcer disease [1-6]. Seropositivity for $H$. pylori has been shown to correlate with the incidence of gastric cancer in many countries 
Table 2. Identification by PCR of cagAPAI in $H$. pylori-positive biopsy specimens from 130 children and 52 adults

\begin{tabular}{lccc}
\hline & \multicolumn{3}{c}{ Number (\%) of samples that were } \\
\cline { 2 - 4 } Disease state (n, \%) & cagA+ & cagA- & cagA+cagA- \\
\hline Children & $72(55.3)$ & $12(9.2)$ & $2(1.5)$ \\
G $(86,66.1)$ & $1(0.8)$ & 0 & 0 \\
UD+G (1,0.8) & $1(0.8)$ & 0 & 0 \\
DUO $(1,0.8)$ & $1(0.8)$ & 0 & 0 \\
DUO+G (1,0.8) & $22(16.9)$ & $18(13.9)$ & $1(0.8)$ \\
N $(41,31.5)$ & $93(74.6)$ & $30(23.1)$ & $3(2.3)$ \\
Total $(130)$ & $37(71.2)$ & $4(7.7)$ & $1(1.9)$ \\
Adults & $1(1.9)$ & 0 & 0 \\
G $(42,80.8)$ & $2(3.8)$ & 0 & 0 \\
DUO (1, 1.9) & $4(7.7)$ & $3(5.8)$ & 0 \\
DUO+G $(2,3.8)$ & $44(84.6)$ & $7(13.5)$ & $1(1.9)$ \\
N $(7,13.5)$ & Total $(52)$ &
\end{tabular}

G, gastritis; G+DUO, gastritis + duodenitis; UD+G, duodenal ulcer + gastritis; N, normal mucosa; DUO, duodenitis.

$[1,23]$. Early detection of infection may be a crucial factor in preventing the more serious consequences of $H$. pylori infection of gastric mucosa $[1,2,5,6,9]$.

The diagnostic techniques adapted to identify H. pylori infection can be divided into invasive and non-invasive methods. The non-invasive assays that do not require upper gastrointestinal endoscopy to biopsy specimens include serological testing for the presence of antibodies against $H$. pylori, or the urea breath tests (UBT) with ${ }^{13} \mathrm{C}$ - or ${ }^{14} \mathrm{C}$-labelled urea [24, 25]. Serological methods, well suited for epidemiological purposes, have some limitations in the differentiation of current active $H$. pylori infection from past $H$. pylori infection and in evaluating the efficacy of treatment directed at eradication of the organism $[26,27]$. The sensitivity and specificity of the UBT are comparable with culture and histology, but costs and time-consuming procedures are reported as disadvantages [28]. The biopsy specimens can be analysed for the presence of $H$. pylori directly by histological staining techniques, culture, microscopic examination and the rapid urease test. The latter two are reported as having low sensitivity and specificity [19]. Although culture rather than histopathological examination is considered to be the gold standard [29], culture is difficult and false negative results cannot be excluded. Failure of culture can be explained by lack of experience, incorrectly prepared media, or unsuitable incubation conditions, and prolonged use of inappropriate transport medium for biopsy specimens. Major advantages of culturing for $H$. pylori include the possibility of antimicrobial susceptibility testing and detailed characterisation of the isolates.

The goal of this study was to evaluate the presence of $H$. pylori infection in a large cohort of Polish symptomatic children and adults by specific detection of $H$. pylori urease A gene (ureA) by PCR. In addition, the PCR technique was used to characterise the virulence-associated cagPAI, correlated as it is with higher risk for the development of more serious consequences of infection.

Previous comparative studies of the sensitivity of PCR and culture in the detection of $H$. pylori were mostly based on $<50$ samples $[19,20,30-32]$, or $50-100$ samples $[3,26,28,34]$ and showed similar sensitivity of both methods [28], or higher sensitivity of PCR than culture $[3,19,28,31-33]$. In the present cohort study of 246 children and 74 adults, the overall sensitivity of PCR $(98.3 \%)$ was higher than that of culture $(81.1 \%)$. It was possible to detect 50 cells of $H$. pylori in a clinical sample, giving a sensitivity range comparable with that of Clayton et al. [20], Hammar et al. [19] and others [24, 28, 30, 31, 33, 34]. The higher sensitivity of ureA-specific PCR compared with culture allowed the identification of $H$. pylori infection in an additional 35 children and five adults. Lower levels of $H$. pylori colonisation in the gastric mucosa might be responsible for culture failure. Moreover, 26 children and three adults presented with normal mucosa, suggesting fresh infection. These results seemed to be in agreement with those of Mapstone et al. [30] and Clayton et al. [20], who found that some patients with normal mucosa were colonised with $H$. pylori, as well as patients with chronic gastritis who had not been infected with H. pylori. By strictly following the rules for sample transportation times, the present study reduced the risk of making the target micro-organism non-culturable or dead [26]. The higher sensitivity of ure $A$-specific PCR also allowed the identification of infection in five patients on specific therapy and in whom negative cultures suggested succesful eradication. It can be speculated that the lack of positive culture in these patients might reflect the relatively low number of bacteria persisting after therapy and without PCR assay such patients would be deemed to be healthy subjects and could be at high risk of recurrence of infection by the remaining bacteria, reactivation of chronic gastritis and increasing liability to ulcer disease. The results of the present study suggest that 
the sensitivity of ureA-specific PCR makes it valuable in patient management, not only for precise diagnosis but also for evaluation of treatment efficacy.

In general, $H$. pylori was detected more often by PCR than by culture $(70.3 \%$ compared with $52.8 \%$ in children and $62.8 \%$ compared with $38.6 \%$ in adults). Although DNA extracts were used - which are more efficient PCR targets than boiled biopsy lysates and are associated with decreased numbers of inhibitory agents after phenol-chloroform extraction [32,35] negative results for $\beta$-globin gene were found in seven $H$. pylori negative samples, suggesting the presence of inhibitors. These exceptions in which PCR did not detect infections that were detected by culture may be attributable to sequence divergence in a PCR binding site or patchiness of $H$. pylori growth in infected carriers, but no additional tests with more biopsy samples or other primers were performed to investigate these possibilities.

H. pylori was detected by ureA-specific PCR in 83 $(76.9 \%)$ of 108 children and in $41(87.2 \%)$ of 47 adults with histological evidence of gastritis, and also in $38(28.4 \%)$ of 134 children and $7(29.5 \%)$ of 24 adults with normal gastric mucosa. Among 124 children and 51 adults found to be positive by PCR, 89 and 46 patients, respectively, also had positive cultures. Thus, there was generally quite good concordance between these tests, although PCR with $u$ re $A$-specific primers was considerable more sensitive, faster and less laborious than culture. Serological examinations showed that $45 \%$ [36] $-65.5 \%$ (personal communication with Dr U. Wojda, Department of Clinical Microbiology, CMHI) of symptomatic children aged 2-18 and 9-18 years, respectively, are seropositive. The present study indicated that the rate of $H$. pylori infection increases from $5.4 \%$ at 5 years of age to $29.2 \%$ at 10 years and to $65.4 \%$ at age 18 years. Thus, it is postulated that PCR can be a useful additional diagnostic test for $H$. pylori.

It has been suggested that positive cagA status of $H$. pylori infection is epidemiologically associated with the development of peptic ulceration and with an increased tendency to develop atrophic gastritis, intestinal metaplasia and gastric cancer [37,38]. However, until now it has been recognised that some genes throughout the 37-kb cagPAI (both within cagI and cagII) may participate in the induction of IL-8 synthesis and resultant inflammation, as it has been shown that they are needed to elicit synthesis of IL-8 in cultured epithelial cells [15].

This study demonstrated that PCR with cagPAI- and 'empty site' of cagPAI-specific primers is an accurate and rapid assay for identifying $H$. pylori strains carrying cagPAI (detection of the left end of the whole $37-\mathrm{kb}$ pathogenicity island), lacking cagPAI (detection of the sequences adjacent to the $37-\mathrm{kb}$ pathogenicity island) and mixed infection by strains carrying both the cagPAI and 'empty site' of the cagPAI (Fig. 1). As many as $74.6 \%$ and $84.6 \%$ PCRureA-positive biopsy specimens taken from children and adults were infected with cagPAI $+H$. pylori strains. Other PCR ureA+ biopsy specimens were negative for cagPAI and contained 'empty site'; four patients were found to be infected with a mixture of cag + and cag - variants, reflecting a very low level of the mixed cag + cag - infections. In these cases, two different strains maybe present, but this result does not rule out the possibility of cag + and cag - variants of the same strain. This issue needs further study. Also, a PCR just for cagA or left or right end of cagPAI does not exclude the possibility that the cag pathogenicity island is completely deleted, but cases where the cagI segment may be deleted and cagII may be still present (or vice versa) are very rare [15].

In cases of gastritis, infection with cagPAI $+H$. pylori was found in $84.0 \%$ and $88 \%$ of children and adults, respectively. Half of the patients revealed the presence of $H$. pylori cagPAI in biopsy samples where no mucosal changes were seen. This is in accord with the generally lower virulence of cag- strains.

Data obtained from the present study indicate that the frequency of $H$. pylori infection in Polish children, is two to three-fold higher than in Belgium, where only $26.3 \%$ of symptomatic children were $H$. pylori culture positive [29]. Moreover the number of $H$. pyloriinfected young asymptomatic Polish individuals is seven times higher $[29,39]$. It is suggested that in addition to their importance in diagnosis, such data will provide a critical baseline for future projection of epidemiological trends. The high incidence of cag+ $H$. pylori strains in children suggests that this population may be at risk of developing more serious pathologies of the gastric mucosa [40].

\section{References}

1. Labigne A, de Reuse H. Determinants of Helicobacter pylori pathogenicity. Infect Agents Dis 1996; 5: 191-202.

2. Lee A. The microbiology and epidemiology of Helicobacter pylori infection. Scand J Gastroenterol 1994; 29 Suppl 201: $2-6$.

3. Lage AP, Godfroid E, Fauconnier A et al. Diagnosis of Helicobacter pylori infection by PCR: comparison with other invasive techniques and detection of cagA gene in gastric biopsy specimens. J Clin Microbiol 1995; 33: 2752-2756.

4. Lee A, Fox J, Hazell S. Pathogenicity of Helicobacter pylori: a perspective. Infect Immun 1993; 61: 1601-1610.

5. McCallion WA, Murray LJ, Baille AG, Dalzell AM, O'Reilly DPJ, Bamford KB. Helicobacter pylori infection in children: relation with current household living conditions. Gut 1996; 39: $18-21$.

6. Moss S, Calam J. Helicobacter pylori and peptic ulcers: the present position. Gut 1992; 33: 289-292.

7. Matysiak-Budnik T, Megraud F. Helicobacter pylori in eastern european countries: what is the current status? Gut 1994; 35: $1683-1686$.

8. Solnick JV, Tompkins LS. Helicobacter pylori gastroduodenal disease: pathogenesis and host-parasite interaction. Infect Agents Dis 1992; 1: 294-309. 
9. Mendall MA, Northfield TC. Transmission of Helicobacter pylori infection. Gut 1995; 37: 1-3.

10. Vorobjova $T$, Kisand $\mathrm{K}$, Haukanomm A, Maaroos HI, Wadstrom T, Uibo R. The prevalence of Helicobacter pylori antibodies in a population from southern Estonia. Eur $J$ Gastroenterol Hepatol 1994; 6: 529-533.

11. Tamassy K, Simon L, Francis M. Epidemiology of Helicobacter pylori infection in Hungary. Orv Hetil 1995; 136: 1387-1391.

12. Czkwianianc E, Bạk-Romaniszyn L, Małecka-Panas E, Suski S, Woch G. Prevalence of Helicobacter pylori in children depends on age and living conditions. J Physiol Pharmacol 1996; 47: 203-207.

13. Ordera G, Figura N, Bayeli PF et al. Serologic IgG recognition of Helicobacter pylori cytotoxin-associated protein, peptic ulcer and gastroduodenal pathology in childhood. Eur $J$ Gastroenterol Hepatol 1993; 5: 695-699.

14. Akopyants NS, Kersulyte D, Berg DE, DNA rearrangements in the $40 \mathrm{~kb}$ cag (virulence) region in the $H$. pylori genome. Gut 1996; 39 Suppl 2: A67-68 (Abstract).

15. Alopyants NS, Clifton SW, Kersulyte D et al. Analyses of the cag pathogenicity island of Helicobacter pylori. Mol Microbiol 1998; 28: 37-53.

16. Megraud F, Bonnet F, Garnier M, Lamouliatte H. Characterization of 'Campylobacter pyloridis' by culture, enzymatic profile, protein content. J Clin Microbiol 1985; 22: 1007-1010.

17. Price AB. The Sydney System: histological division. J Gastroenterol Hepatol 1991; 6: 209-222.

18. Tomb J-F, White O, Kerlavage AR et al. The complete genome sequence of the gastric pathogen Helicobacter pylori. Nature 1997; 388: 539-547.

19. Hammar M, Tyszkiewicz T, Wadström T, O'Toole PW. Rapid detection of Helicobacter pylori in gastric biopsy material by polymerase chain reaction. $J$ Clin Microbiol 1992; 30: 54-58.

20. Clayton CL, Kleanthous H, Coates PJ, Morgan DD, Tabaqchali S. Sensitive detection of Helicobacter pylori by using polymerase chain reaction. $J$ Clin Microbiol 1992; 30: 192-200.

21. Drouet E, Michelson S, Denoyel G, Colimon R. Polymerase chain reaction detection of human cytomegalovirus in over 2000 blood specimens correlated with virus isolation and related to urinary virus excretion. $J$ Virol Methods 1993; 45: 259-276.

22. Fox JC, Ait-Khaled M, Webster A, Emery VC. Eliminating PCR contamination: is UV irradiation the answer? $J$ Virol Methods 1991; 33: 375-382.

23. Matsukura N, Onda M, Tokunaga A, Kato S, Yamashita K, Ohbayashi M. Detection of Helicobactr pylori DNA in gastric juice by the polymerase chain reaction: comparison with findings in bacterial culture and the detection of tissue $\operatorname{IgA}$ and serum IgG antibodies against Helicobacter pylori. $J$ Gastroenterol 1995; 30: 685-695.

24. Ho SA, Hoyle JA, Lewis FA et al. Direct polymerase chain reaction test for detection of Helicobacter pylori in humans and animals. J Clin Microbiol 1991; 29: 2543-2549.

25. Glupczynski Y, Goossens H, Burette A, Deprez C, van Borre C, Butzler JP. Serology in Helicobacter pylori infection. Int $J$ Med Microbol Virol Parasitol Infect Dis 1993; 280: 150-154.
26. Weiss J, Mecca J, Da Silva E, Gassner D. Comparison of PCR and other diagnostic techniques for detection of Helicobacter pylori infection in dyspeptic patients. J Clin Microbiol 1994; 32: $1663-1668$.

27. Cutler A, Schubert A, Schubert T. Role of Helicobacter pylori serology in evaluating treatment success. Dig Dis Sci 1993; 38: $2262-2266$.

28. van Zwet AA, Thijs JC, Kooistra-Smid AMD, Schirm J, Snijder JA. Sensitivity of culture compared with that of polymerase chain reaction for detection of Helicobacter pylori from antral biopsy samples. J Clin Microbiol 1993; 31: 1918-1920.

29. Blecker U, Lanciers S, Hauser B, Vandenplas Y. Diagnosis of Helicobacter pylori infection in adults and children by using the Malakit Helicobacter pylori, a commercially available enzyme-linked immunosorbent assay. J Clin Microbiol 1993; 31: $1770-1773$.

30. Mapstone NP, Lynch DAF, Lewis FA et al. Identification of Helicobacter pylori DNA in the mouths and stomachs of patients with gastritis using PCR. J Clin Pathol 1993; 46: $540-543$.

31. Valentine JL, Arthur RR, Mobley HLT, Dick JD. Detection of Helicobacter pylori by using the polymerase chain reaction. $J$ Clin Microbiol 1991; 29: 689-695.

32. Wang JT, Lin JT, Sheu JC, Yang JC, Chen DS, Wang TH. Detection of Helicobacter pylori in gastric biopsy tissue by polymerase chain reaction. Eur $J$ Clin Microbiol Infect Dis 1993; 12: $367-371$.

33. Bickley J, Owen RJ, Fraser AG, Pounder RE. Evaluation of the polymerase chain reaction for detecting the urease $\mathrm{C}$ gene of Helicobacter pylori in gastric biopsy samples and dental plaque. $J$ Med Microbiol 1993; 39; 338-344.

34. Westblom TU, Phadnis S, Yang P, Czinn SJ. Diagnosis of Helicobacter pylori infection by means of a polymerase chain reaction assay for gastric juice aspirates. Clin Infect Dis 1993; 16: $367-371$.

35. Shames B, Fox JG, Dewhirst F, Uan L, Shen Z, Taylor NS. Identification of widespread Helicobacter hepaticus infection in faeces in commercial mouse colonies by culture and PCR assay. J Clin Microbiol 1995; 33: 2968-2972.

36. Gościniak G, Klakockar J, Przondo-Mordarska A, Mauff G. Helicobacter pylori antibodies in sera of children suffering from chronic abdominal pain. Int $J$ Med Microbiol Virol Parasitol Infect Dis 1993; 280: 214-220.

37. Peek RM, Miller GG, Tham KT et al. Detection of Helicobacter pylori gene expression in human gastric mucosa. $J$ Clin Microbiol 1995; 33: 28-32.

38. Muszyński J, Biernacka D, Siemińska J et al. [Changes in gastric mucosa and Helicobacter pylori infection in young health volunteers.] Pol Merkuriusz Lek 1996; 1: 169-173 (in Polish).

39. Husson M-O, Gottrand F, Vachee A et al. Importance in diagnosis of gastritis of detection by PCR of the cagA gene in Helicobacter pylori strains isolated from children. $J$ Clin Microbiol 1995; 33: 3300-3303.

40. Cover TL, Glupczynski Y, Lage AP et al. Serologic detection of infection with cagA + Helicobacter pylori strains. $J$ Clin Microbiol 1995; 33: 1496-1500. 